\title{
1 Strong temporal variation in treefall and branchfall rates in a tropical 2 forest is explained by rainfall: results from five years of monthly drone 3 data for a 50-ha plot
}

4

.

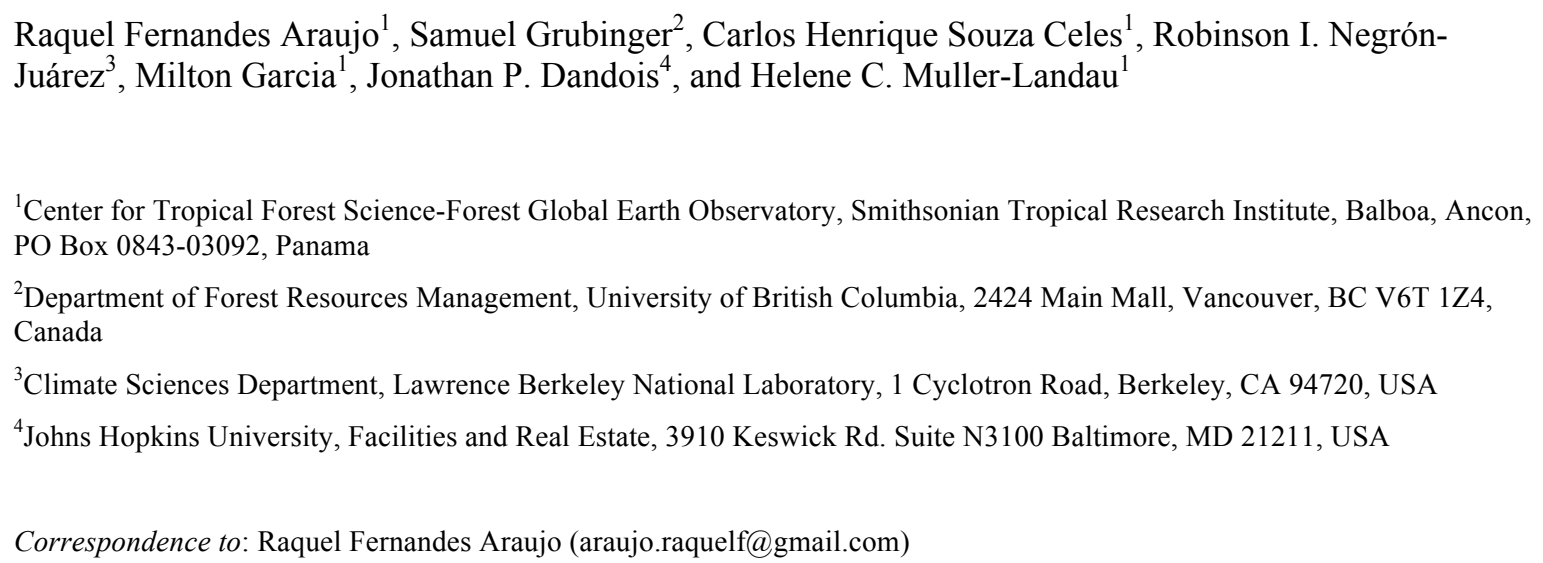

Abstract. A mechanistic understanding of how tropical tree mortality responds to climate variation is urgently needed to predict how tropical forest carbon pools will respond to anthropogenic global change, which is altering the frequency and intensity of storms, droughts, and other climate extremes in tropical forests. We used five years of approximately monthly drone-acquired RGB imagery for 50 ha of mature tropical forest on Barro Colorado Island, Panama, to quantify spatial structure, temporal variation, and climate correlates of canopy disturbances, i.e., sudden and major drops in canopy height due to treefalls, branchfalls, or collapse of standing dead trees. Treefalls accounted for $77 \%$ of the total area and $60 \%$ of the total number of canopy disturbances in treefalls and branchfalls combined. The size distribution of canopy disturbances was close to a power function for sizes above $25 \mathrm{~m}^{2}$, and best fit by a Weibull function overall. Canopy disturbance rates varied strongly over time and were higher in the wet season, even though windspeeds were lower in the wet season. The strongest correlate of temporal variation in canopy disturbance rates was the frequency of 1-hour rainfall events above the $99.4^{\text {th }}$ percentile (here $35.7 \mathrm{~mm} \mathrm{hour}^{-1}, \mathrm{r}=0.67$ ). We hypothesize that extreme high rainfall is associated with both saturated soils, increasing risk of uprooting, and with gusts having high horizontal and vertical windspeeds that increase stresses on tree crowns. These results demonstrate the utility of repeat droneacquired data for quantifying forest canopy disturbance rates over large spatial scales at fine temporal and spatial resolution, thereby enabling strong tests of linkages to drivers. Future studies should include high frequency measurements of vertical and horizontal windspeeds and soil moisture to better capture proximate drivers, and incorporate additional image analyses to quantify standing dead trees in addition to treefalls.

\section{Introduction}

Tropical forests account for two-thirds of terrestrial biomass carbon stocks (Pan et al., 2013), and uncertainty regarding the future of these stocks is a major contributor to uncertainty in the future global carbon cycle (Cavaleri et al., 2015). Tropical 
https://doi.org/10.5194/bg-2021-102

Preprint. Discussion started: 20 April 2021

(C) Author(s) 2021. CC BY 4.0 License.

(c) (i)

37 forest carbon stocks depend critically on tree mortality rates, and theory and evidence suggest tropical tree mortality rates may be

38 increasing due to anthropogenic global change (Brienen et al., 2015; McDowell et al., 2018). Tropical tree mortality can be caused

39 by a diversity of drivers including storms, droughts, fires, lightning strikes, and biotic agents (McDowell et al., 2018; Yanoviak et al., 2017; Fontes et al., 2018; Silva et al., 2018). The frequency of extreme rainfall and drought events is expected to increase in

41 tropical regions, potentially increasing associated tree mortality (IPCC, 2014; Deb et al., 2018; Aubry-Kientz et al., 2019). An

42 improved understanding of the processes of forest disturbance is critical to constrain estimates of current and future carbon cycling

43 in tropical forests under alternative emissions scenarios (Leitold et al., 2018).

Despite the importance of tree mortality to forest structure and carbon turnover rates, the mechanisms underlying tree mortality remain unclear (McDowell et al., 2018). A key problem is that remeasurement intervals of permanent plots average five or more years, making it difficult to link mortality variation with particular climatic events (Phillips et al., 2010; Davies et al., 2021; Arellano et al., 2019). The high rates of decomposition in tropical forests further obscure evidence of underlying mechanisms and risk factors (Arellano et al., 2019). The few studies that have quantified temporal variation of tree mortality at monthly and bimonthly scales using ground-based data have all found higher tree mortality in times of higher rainfall (Brokaw, 1982; Fontes et al., 2018; Aleixo et al., 2019). This is consistent with the understanding that many trees die in treefalls, which are proximately caused by trunk breakage or uprooting, and are associated with storms (Marra et al., 2014; Araujo et al., 2017; Fontes et al., 2018; Negrón-Juárez et al., 2018; Esquivel-Muelbert et al., 2020). The collection of additional high temporal resolution mortality data over large areas, together with high temporal resolution climatological data, can aid in linking mortality to particular climatic events and thereby elucidating mortality mechanisms (Arellano et al., 2019; McMahon et al., 2019).

Drone-acquired aerial imagery and photogrammetry software now provide excellent tools for monitoring forest canopies (Araujo et al., 2020) and repeat drone flights can quantify canopy dynamics over large areas at high temporal resolution.

57 Photogrammetric analysis of simple RGB imagery enables reconstruction of the appearance and three-dimensional structure of the top of the canopy at high spatial resolution (Dandois and Ellis, 2013; Araujo et al., 2020; Zahawi et al., 2015). Comparison of photogrammetry products from successive drone flights allows easy detection and quantification of treefalls and branchfalls of canopy trees. Canopy trees constitute a high proportion of stem density, aboveground carbon stocks and wood productivity (Araujo et al., 2020), and thus information on their dynamics is disproportionately useful. Treefalls do not necessarily result in tree mortality (trees may survive and resprout), but all treefalls and branchfalls result in a large flux of carbon (wood) from biomass to necromass, i.e., biomass turnover, which translates to reduced woody residence time. Periods of higher canopy disturbance rates

64 thus represent periods of higher biomass turnover, and likely correlate with higher tree mortality rates. Further, even when trees

65 don't die from a canopy disturbance event, suffering crown loss or damage increases the risk of subsequent mortality (Arellano et 66 al., 2019).

Monitoring canopy disturbances with drones also provides the opportunity to precisely quantify the size distributions of these canopy disturbances, and to distinguish branchfalls from treefalls. Here we define a canopy disturbance as a substantial decrease in canopy height in a contiguous patch of canopy occurring over one measurement interval, such as typically results from a treefall or branchfall. Marvin and Asner (2016) and Dalagnol et al. (2021) referred to these as "dynamic canopy gaps." By definition, canopy disturbances reduce canopy height and thereby change light regimes for understory and neighboring trees, and the magnitude of the change depends on the disturbance size in area and depth (Hubbell et al., 1999). In general, larger canopy disturbances cause larger canopy gaps as traditionally measured on the ground. Previous studies have analyzed the size distributions

74 of static gaps for insights into forest structure, habitat niches, and disturbance regimes (e.g., Manrubia and Solé, 1997; Lobo and 75 Dalling, 2013, 2014; Fisher et al., 2008). Tree species respond differently to canopy gaps of different sizes, with small gaps favoring 
https://doi.org/10.5194/bg-2021-102

Preprint. Discussion started: 20 April 2021

(C) Author(s) 2021. CC BY 4.0 License.

(c) (i)

76 a different set of species than large gaps (Brokaw, 1985; Denslow, 1980, 1987; Dalling et al., 2004). Branchfalls, like treefalls, are

77 important in generating canopy gaps and contributing to woody turnover, but also often go unmeasured (Marvin and Asner, 2016;

78 Leitold et al., 2018). Quantifying tree mortality and other non-fatal damage such as branchfall thus contributes to a better understanding on change of forest structure, necromass estimates and nutrient cycling.

Here, we use 5 years of $\sim$ monthly drone-acquired RGB imagery for a 50 ha area of mature tropical forest on Barro Colorado Island, Panama, to investigate canopy dynamics at high temporal resolution. We aim to (1) quantify temporal variation in canopy disturbance rates and its relationship to climate variation; (2) characterize the size structure of canopy disturbances; and

83 (3) evaluate the role of branchfalls in canopy dynamics. We expect that disturbance rates will be higher in the wet season than the 84 dry season, and will increase with the frequency of extreme rainfall and wind events, and we compare models differing in the 85 conditions for defining such extreme events. To characterize the size structure of canopy disturbances, we quantify the size (area) 86 distribution and evaluate whether it is best fit by power, Weibull, or exponential functions. Finally, we quantify the proportion of canopy disturbance due to branchfalls (rather than treefalls), and test whether branchfalls and treefalls exhibit similar patterns of temporal variation. Our results provide new insights into the patterns and drivers of canopy disturbance and tree mortality in this tropical forest, and illustrate the utility of drones for quantifying canopy dynamics over large areas at high temporal resolution.

\section{2. Methods}

\subsection{Study site}

Barro Colorado Island (BCI; $9^{\circ} 9^{\prime} \mathrm{N}, 79^{\circ} 50^{\prime} \mathrm{W}$ ) is a $15 \mathrm{~km}^{2}$ island in Central Panama, that was isolated from surrounding mainland when Lake Gatun was created as part of the construction of the Panama Canal. BCI supports tropical moist forest in the Holdridge Life Zone System (Holdridge, 1947). Annual precipitation averages approximately $2600 \mathrm{~mm}$, with a pronounced dry season between January and April (a mean of about 3.5 months with $<100 \mathrm{~mm} \mathrm{mo}^{-1}$ ). Mean annual temperature is $26^{\circ} \mathrm{C}$ and varies little throughout the year (Windsor, 1990). The 50 ha forest dynamics plot (1000 m x $500 \mathrm{~m}$ ) was established on BCI in 1981 (Hubbell et al., 1999). It is located in old-growth forest (Leigh, 1999), with the exception of a small area of 1.92 ha of old secondary forest ( $\sim 100$ years old) in the north central part of the plot (Harms et al., 2001).

\subsection{Meteorological data}

Meteorological data were collected in the lab clearing and Lutz tower, approximately $1.7 \mathrm{~km} \mathrm{NE}$ of the center of the 50 ha plot. Wind speed was measured using an anemometer (RM Young Wind Monitor Model 05103) installed at the top of Lutz tower, at $48 \mathrm{~m}$ height above ground and approximately $6 \mathrm{~m}$ above the top of the surrounding canopy. The maximum wind speed was recorded for every 15 minute-interval. Rainfall was measured in the lab clearing using a tipping bucket (Hydrological Services Model TB3), and recorded every 5 minutes; we aggregated these data to 15 -minute periods to match the temporal resolution of the

$$
\text { speed data. }
$$

Rainfall and wind speed data are available in

109 https://biogeodb.stri.si.edu/physical_monitoring/research/barrocolorado. The meteorological record had no gaps during our study period (Fig. S1). 
https://doi.org/10.5194/bg-2021-102

Preprint. Discussion started: 20 April 2021

(c) Author(s) 2021. CC BY 4.0 License.

(c) (1)

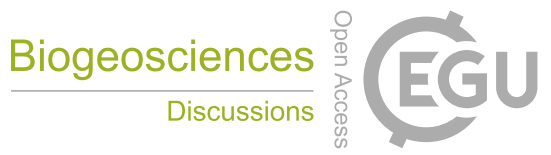

\section{$112 \quad 2.3$ Canopy disturbance identification}

We used approximately monthly orthomosaics and canopy surface models produced from drone-acquired imagery to analyze temporal variation in canopy disturbance rates in the 50 ha plot between 2 October 2014 and 28 November 2019. RGB imagery was collected using a variety of drones and cameras over the years, with a horizontal spatial resolution of $3-7 \mathrm{~cm}$. Imagery for each sampling date was processed using the photogrammetry software Agisoft Metashape to obtain orthomosaics and surface elevation models, which were then aligned vertically and horizontally (details in Text S1).

We defined a canopy disturbance as a substantial decrease in canopy height in a contiguous patch of canopy occurring over one measurement interval, such as typically results from a treefall or branchfall. We identified canopy disturbances through a combination of analysis of the canopy surface model changes and visual interpretation of the orthomosaics (Fig. 1). We first differenced surface elevation models for successive dates to obtain a raster of the canopy height changes for the associated interval (Fig. 1, Text S1). We then pre-delineated major canopy disturbances by filtering for areas in which canopy height decreased more than $10 \mathrm{~m}$ in contiguous areas of at least $25 \mathrm{~m}^{2}$ (the minimum area for canopy gaps in previous studies by Brokaw (1982) and Hubbell et al. (1999)), and that had an area-to-perimeter ratio greater than 0.6. (The area-to-perimeter condition removes artifacts associated with slight shifts in the measured positions of individual trees from one image set to another, whether due to wind or alignment errors.) Finally, we systematically examined orthomosaic images for 1-ha square subplots for each pair of successive dates and edited the pre-delineated polygons, removed false positives, and added visible new canopy disturbances that were not previously delineated (whether because they were too small in area or in canopy height drop). During the visual inspection of the data for the last three years we also classified disturbances as being due to treefalls (a whole previously live tree fell, creating a clearly visible gap on the forest floor, or the whole live crown disappeared), branchfalls (a portion of a live crown broke), or standing dead trees disintegrating (Fig. S2). 
https://doi.org/10.5194/bg-2021-102

Preprint. Discussion started: 20 April 2021

(c) Author(s) 2021. CC BY 4.0 License.
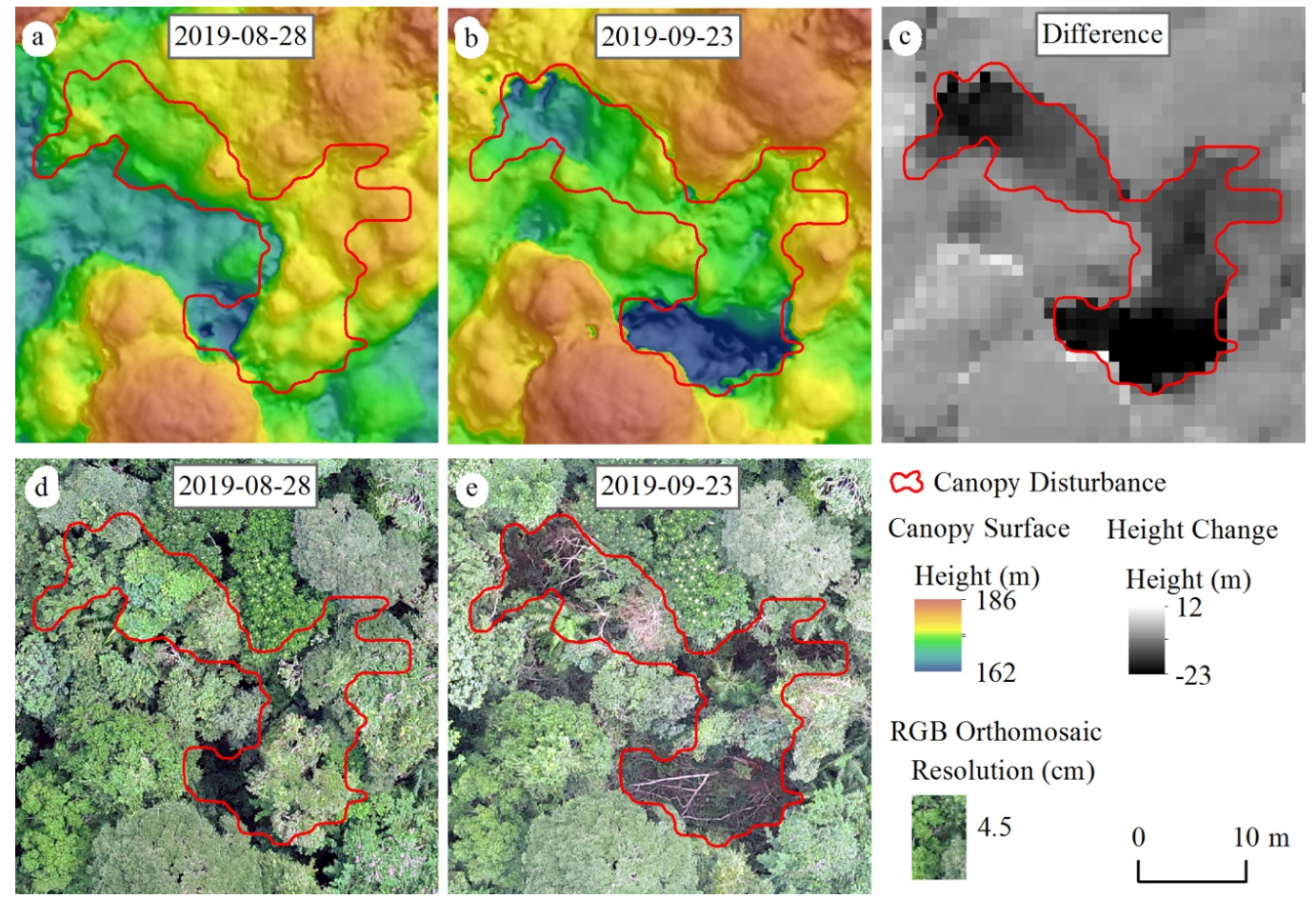

Canopy Disturbance

Canopy Surface Height Change

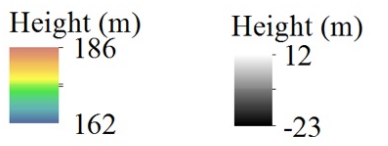

RGB Orthomosaic

Resolution (cm)

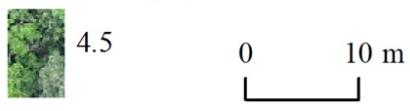

134 Figure 1. Canopy disturbance visualized on canopy surface models and orthomosaics calculated from photogrammetric analyses of drone imagery. (a,b) Elevation models for a portion of the study area on two successive dates, 28 August 2019 (a) and 23

136 September 2019 (b). (c) Difference in elevation between the two dates, with black area indicating large decrease in canopy

137 elevation. (d,e) RGB orthomosaics of the same dates.

We calculated the total number and area of canopy disturbances within the BCI 50 ha plot during the five years of the study. In calculating the number and total area of disturbances, we included all disturbed areas that were inside the plot boundaries (if a disturbance was on the boundary, only the area inside the plot was included). Our analyses of temporal variation employed the same definitions for numbers and areas of canopy disturbances within the 50 ha plot. For analyses of the size structure of disturbances, we included the complete areas of disturbances whose centroids were located within the plot (i.e., we excluded disturbances centered outside the plot, and included area outside the plot for disturbances centered inside the plot to avoid artifacts related to reducing disturbance size by trimming at the plot boundaries).

We calculated canopy disturbances rates for each measurement interval as the percentage of area disturbed per month (i.e., per 30-day period). Specifically, we summed the total area disturbed during the measurement interval, and divided by the total area of the plot and the length of the time interval. We excluded one excessively long interval ( 237 days) from all analyses of temporal variation; the remaining intervals ranged from 14 to 91 days, with a median of 31.5 days (Table S1). We also calculated an incidence canopy disturbance rate as the number of canopy disturbances per hectare per month. We calculated the mean, 
https://doi.org/10.5194/bg-2021-102

Preprint. Discussion started: 20 April 2021

(c) Author(s) 2021. CC BY 4.0 License.

(c) (i)

152 minimum, maximum, and the $25^{\text {th }}, 50^{\text {th }}$, and $75^{\text {th }}$ percentiles of interval length in days, number and area of canopy disturbances,

153 and the respective monthly rates.

154 We compared canopy disturbance rates between wet and dry seasons and between early wet and late wet seasons. We defined the dry season as January 1 to April 30 (rainfall $<100 \mathrm{~mm} \mathrm{mo}^{-1}$, Fig. S3), the early wet season as 1 May to 31 August, and the late wet season as 1 September to 31 December. Intervals that straddled more than one season were classified to the season in which they had more days. We tested for homogeneity of variances using the Levene test, and for differences between means using the two-tailed Student's t-test for the log-transformed canopy disturbance rates.

We evaluated the relationship of temporal variation in canopy disturbance rates with temporal variation in climate extremes using linear regressions. We regressed canopy disturbance rates (area per time) against the frequency of extreme rainfall and windspeed events (number per time), for different definitions of extreme events. For example, one definition of an extreme event would be a 15 -minute period with rainfall above the $99^{\text {th }}$ percentile. We evaluated three different temporal grains for defining extreme events (15-minute, 1-hour, and 1-day intervals), for two different meteorological variables (total rainfall and maximum windspeed), and 100 different thresholds, corresponding to every 0.1 percentile increment between the $90^{\text {th }}$ and $99.9^{\text {th }}$ percentile of the corresponding distributions. We compared the predictive ability of these 600 different definitions of extreme events in terms of their Pearson correlations.

\subsection{Size structure of canopy disturbances}

We characterized the size structure of canopy disturbances whose geometric center was inside the plot, excluding disturbances from the one excessively long interval of 237 days. (Longer time intervals increase the likelihood that what is measured as a single disturbance event in fact constitutes multiple adjoining or overlapping events.) We calculated the mean, minimum, maximum, and median of area of individual canopy disturbances. We graphed the cumulative distribution functions with respect to individual disturbance area of number and area of canopy disturbances, to quantify the proportions of canopy disturbances and of total area disturbed below any given size.

We took advantage of the three-dimensional structure of our photogrammetry data to quantify canopy disturbances in terms of their vertical height drop as well as their horizontal area. For each canopy disturbance, we calculated the average height drop from the differences in the canopy surface models. (We excluded 61 canopy disturbances in which heights increased because they reflect errors in the canopy height models.) We evaluated how average height drop was related to area across canopy disturbances, graphically and in terms of their Pearson correlation.

We quantified the size distributions of canopy disturbances by fitting three alternative probability distributions: exponential, power, and Weibull. Recognizing that our methods may miss smaller disturbances, we fit these distributions to truncated datasets, excluding disturbances below 2, 5, 10 or $25 \mathrm{~m}^{2}$. (Note that $25 \mathrm{~m}^{2}$ is the minimum area for defining a canopy disturbance in our automated pre-delineation algorithm, and we are confident we captured all disturbances above this area.) We

184 binned the data into $1 \mathrm{~m}^{2}$ classes, and fitted each distribution to each truncated dataset using maximum likelihood, as described in

185 (Araujo et al., 2020). We compared the goodness of fit of the different functions using Akaike's Information Criterion (AIC). 
https://doi.org/10.5194/bg-2021-102

Preprint. Discussion started: 20 April 2021

(c) Author(s) 2021. CC BY 4.0 License.

For the last three years, for which we classified each canopy disturbance as being a branchfall, treefall, or standing dead tree, we evaluated the relative contributions of branchfalls vs. treefalls. We did not include standing dead trees in the analysis because our methods possibly missed many standing dead trees. We separately calculated treefall and branchfall disturbance rates for each interval, and relative contributions to their summed number and area. We regressed branchfall disturbance rates against treefall disturbance rates, for both area- and number-based rates, and calculated their Pearson correlations.

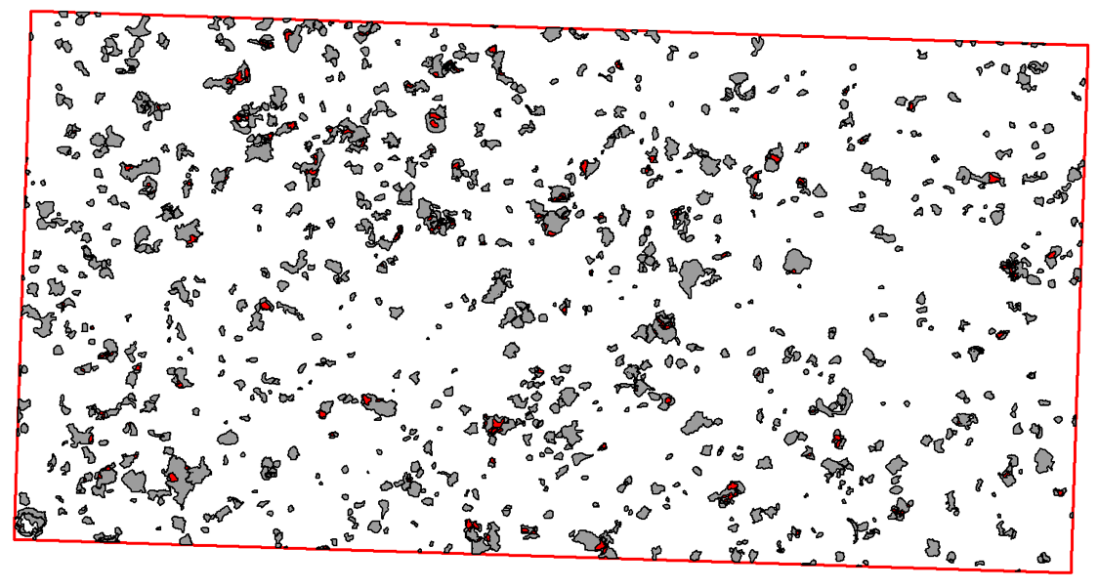

Figure 2. Map of canopy disturbances on the 50 ha plot (red rectangle, 1000 x $500 \mathrm{~m}$ ) on Barro Colorado Island, Panama, from 2 October 2014 to 28 November 2019. Areas that were disturbed a single time are shown in grey, those disturbed more than once in red.

\subsection{Temporal variation in canopy disturbance rates}

Temporal variation analyses included 906 disturbances or partial disturbances encompassing $50,202.8 \mathrm{~m}^{2}$ of area that were located inside the 50 ha plot and were not part of the excluded long interval. There was strong temporal variation in canopy disturbance rates among the 46 time intervals analyzed, with parallel variation in the total area disturbed (Fig. 3) and the number of disturbances (Fig. S4). The mean rate of canopy disturbance creation was $916 \mathrm{~m}^{2} \mathrm{mo}^{-1}$ (range of $75 \mathrm{~m}^{2} \mathrm{mo}^{-1}$ to $8040.9 \mathrm{~m}^{2} \mathrm{mo}^{-1}$ ) 

The single highest disturbance rate was observed between 1 June and 13 July 2016, when $11,257 \mathrm{~m}^{2}$ of disturbances were created

211 in just 42 days (a rate of $268 \mathrm{~m}^{2}$ day $^{-1}$ ). A full $2.3 \%$ of the total area of the plot was converted to new canopy disturbances during 212 this time interval. In contrast, the total area of new disturbances across the rest of the 5-year period was $38,946 \mathrm{~m}^{2}$ (a rate of 24.3 $213 \mathrm{~m}^{2}$ day $\left.^{-1}\right)$.

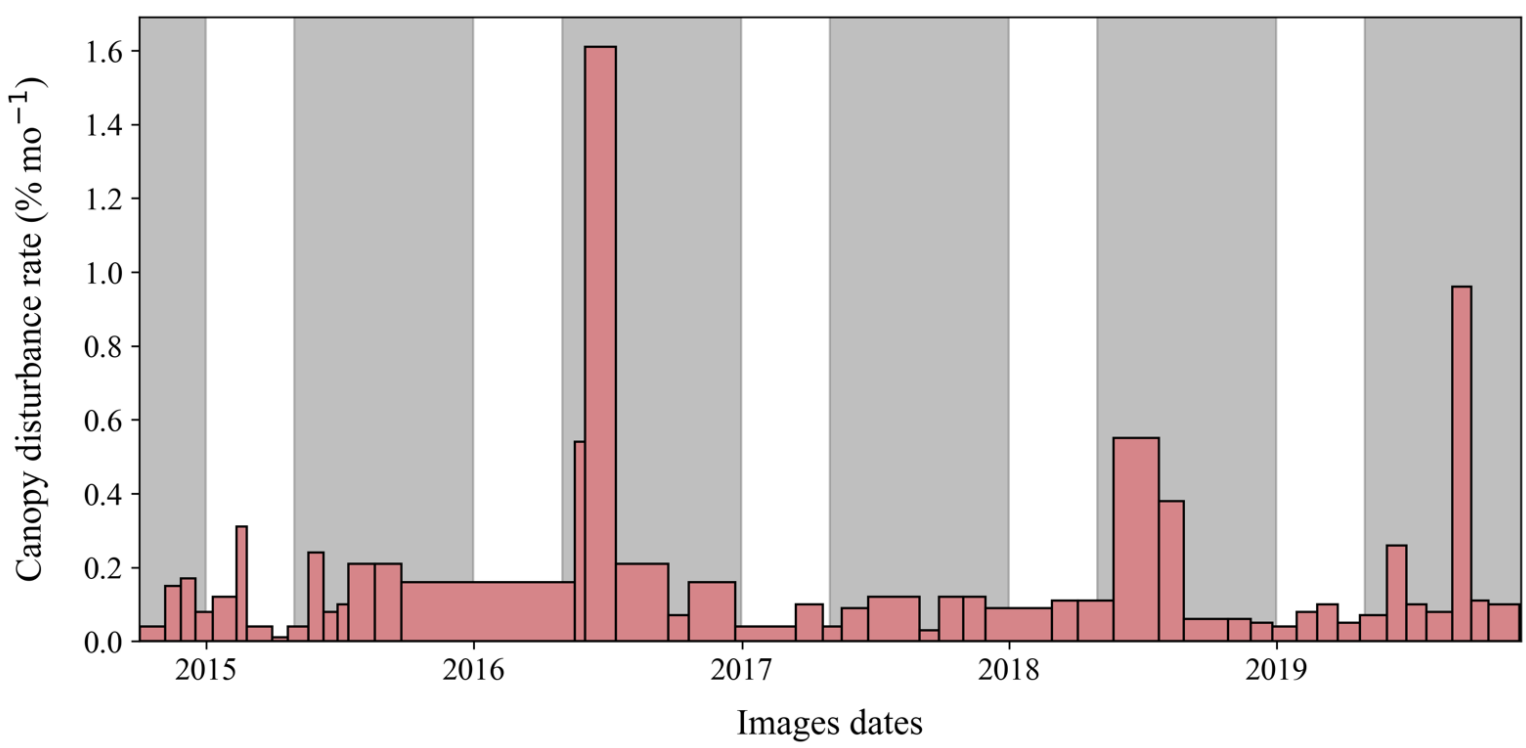

215 Figure 3. Temporal variation in canopy disturbance rates in the 50 ha plot on Barro Colorado Island, Panama, across measurement intervals. Gray shading indicates the wet seasons (May to December) of each year and ticks on the $\mathrm{x}$ axis indicate the first day of each year. Rates are shown in units of percent of area per month (30-day period). Note that the total area of each rectangle is proportional to the total area of canopy disturbed during that measurement interval. only in the wet season. 
(a)

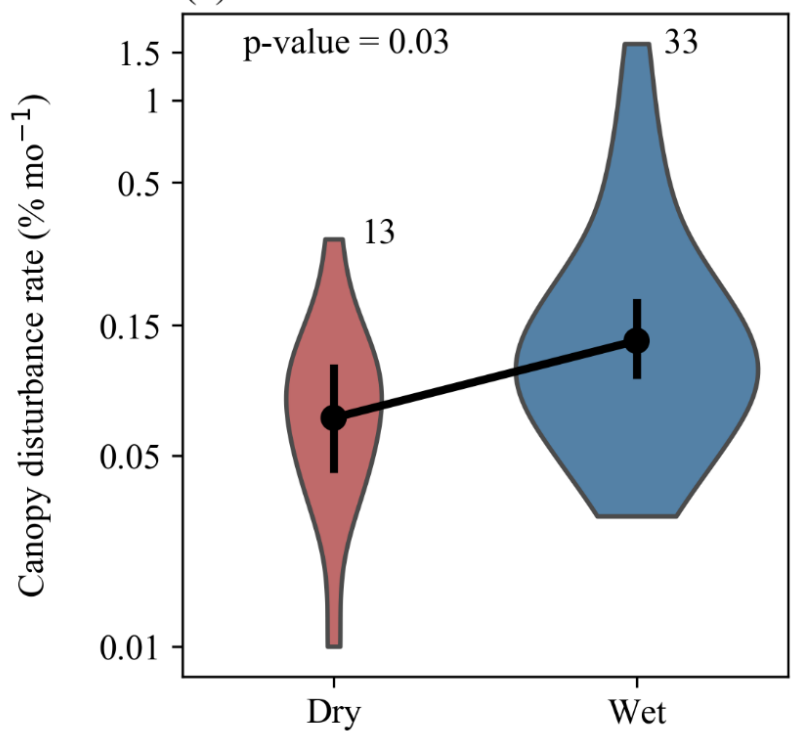

(b)

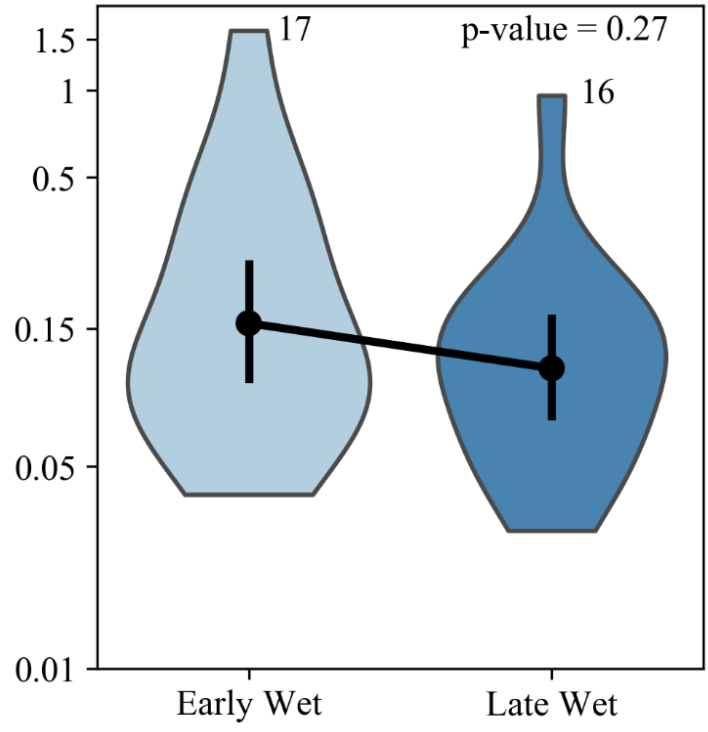

Figure 4. Comparisons of canopy disturbances rates between wet and dry seasons (a), and between early and late wet seasons (b). Violin plots depict the distributions of disturbance rates (\% area disturbed per month) over time intervals, with the number of time intervals listed above each violin plot. Black dots and bars show means and 95\% confidence intervals, respectively.

The best predictor of temporal variation in canopy disturbance rates was the frequency of 1-hour rainfall events above the $99.4^{\text {th }}$ percentile, here $35.7 \mathrm{~mm}_{\text {hour }}{ }^{-1}$, which explained $45 \%$ of the variation (Fig. 5a). This threshold outperformed all other tested rainfall thresholds (all percentiles from 90.0 to 99.9 , by $0.1 \%$ of the different frequency time scales - Fig. 5 b). Only two of these high rainfall events occurred during the same day (Table S2). The measurement interval with the highest disturbance rate (June 1 to July 132016 ) included four such high rainfall events: $41.7 \mathrm{~mm} \mathrm{hour}^{-1}$ on June $17,41.9 \mathrm{~mm}$ hour $^{-1}$ on June $23,49.3 \mathrm{~mm}$ hour ${ }^{-1}$ on June 30, and $36.1 \mathrm{~mm}^{-1}$ hour ${ }^{-1}$ on July 4 (Table S2). The frequency of high horizontal maximum wind speed events was not significantly related with canopy disturbance rates. Indeed, Pearson correlations were negative for almost all wind speed variables (Fig. S6). 
https://doi.org/10.5194/bg-2021-102

Preprint. Discussion started: 20 April 2021

(c) Author(s) 2021. CC BY 4.0 License.

(a)

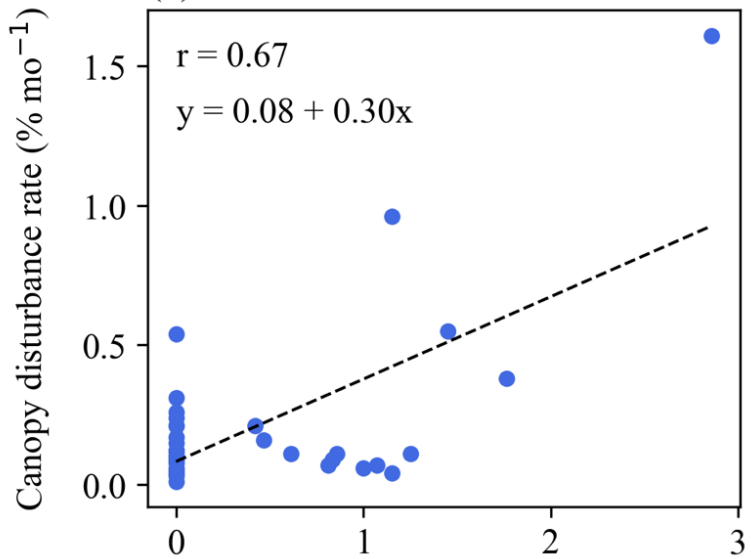

Frequency 1-hour periods with rainfall $>99.4^{\text {th }}\left(\mathrm{mo}^{-1}\right)$ (b)

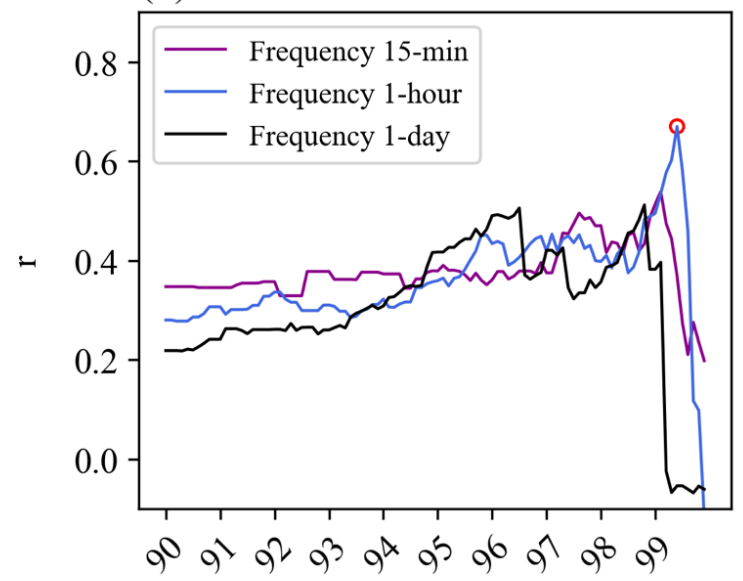

Rainfall percentile thresholds

Figure 5. Relation of temporal variation in canopy disturbance rates to the frequency of extreme rainfall events. (a) The relationship for the single best predictor of canopy disturbance rate: the frequency of 1-hour periods with rainfall exceeding the $99.4^{\text {th }}$ percentile; each point represents one measurement interval, and the dashed line shows the linear regression. (b) Variation in Pearson correlation between canopy disturbance rate and frequency of extreme rainfall events depending on the temporal grain (colors) and percentile threshold ( $\mathrm{x}$ axis) for defining extreme rainfall events; the open red circle indicates the best correlation.

\subsection{Size structure of canopy disturbances}

A total of 878 canopy disturbances with $49,958 \mathrm{~m}^{2}$ total area had their centers inside the plot and were not part of the excluded long interval, and thus were included in the size distribution analyses. The areas of mapped individual canopy disturbances ranged from $2.2 \mathrm{~m}^{2}$ to $486.7 \mathrm{~m}^{2}$, with a mean of $56.9 \mathrm{~m}^{2}$. The median disturbance area was $36.4 \mathrm{~m}^{2}$, whereas $50 \%$ of the total area was in disturbances greater than $86.6 \mathrm{~m}^{2}$ (see Fig. 6a for the full cumulative distributions by gap number and area). Canopy disturbances with larger areas tended to have larger mean decreases in canopy height (Pearson $r=0.39$, Fig. 6b). over the range of 5 to $25 \mathrm{~m}^{2}$ (Fig. 6c). The fitted exponent of the power function was -1.96 for canopy disturbances above $25 \mathrm{~m}^{2}$, but the Weibull distribution provided a better fit than the power function (Table 1). When distributions were fit to data including smaller size classes $\left(>2 \mathrm{~m}^{2},>5 \mathrm{~m}^{2}\right.$ or $\left.>10 \mathrm{~m}^{2}\right)$, the distribution is further from a power function; the Weibull remains the best fit, the exponential becomes the second-best fit, and the power function the worst fit of the three (Fig. S7, Table S3). 
https://doi.org/10.5194/bg-2021-102

Preprint. Discussion started: 20 April 2021

(c) Author(s) 2021. CC BY 4.0 License.

(a)

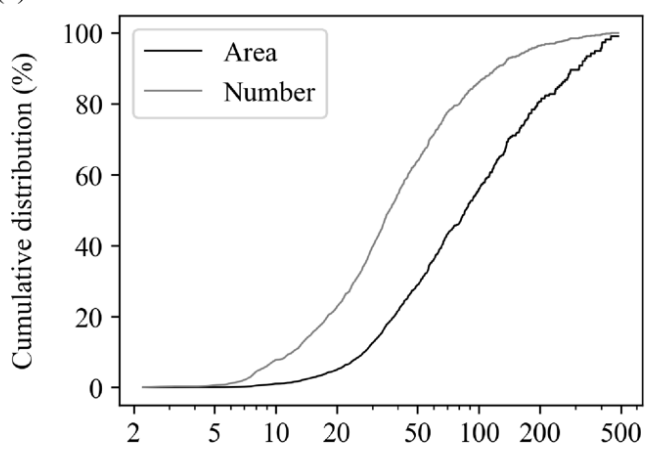

(b)

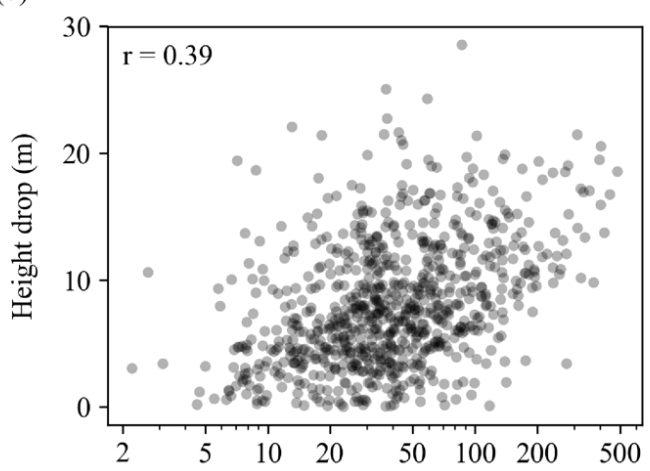

(c)

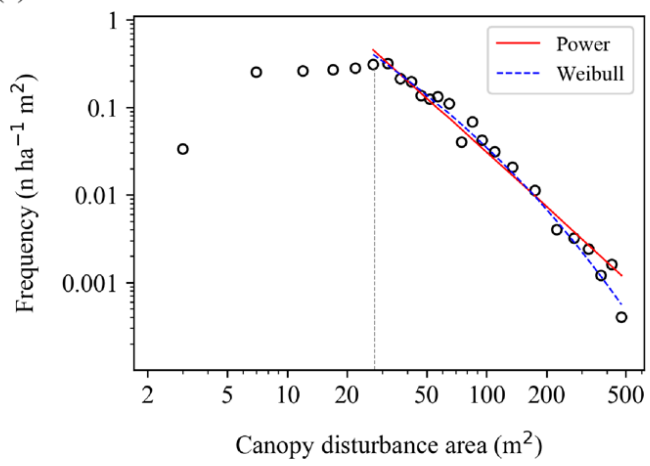

253 Figure 6. Size structure of canopy disturbances. (a) Cumulative number and area of canopy disturbances in relation to their area. (b) Relationship of mean vertical height drop to horizontal area among canopy disturbances. (c) Size distribution of canopy disturbances, together with Weibull and power function fits for canopy disturbances larger than $25 \mathrm{~m}^{2}$ (this threshold was chosen because we are confident we identified all canopy disturbances above this area, but we may have missed some smaller ones). The vertical dashed gray line indicates the $25 \mathrm{~m}^{2}$ threshold. 
https://doi.org/10.5194/bg-2021-102

Preprint. Discussion started: 20 April 2021

(c) Author(s) 2021. CC BY 4.0 License.

Table 1. Parameter values and delta AIC values for maximum likelihood fits of exponential, power and Weibull probability density functions to size distributions for canopy disturbances larger than $25 \mathrm{~m}^{2}$. Delta AIC is the difference in AIC from the best model. The best-fit model is highlighted in bold.

\begin{tabular}{cccc}
\hline Distribution & $\lambda$ & $k$ & Delta AIC \\
\hline Exponential & 0.020 & & 62.45 \\
Power & 1.963 & & 16.50 \\
Weibull & $\mathbf{6 . 7 4 5}$ & $\mathbf{0 . 4 4 8}$ & $\mathbf{0 . 0 0}$ \\
\hline
\end{tabular}

\subsection{Treefalls and branchfalls}

A total of 411 canopy disturbances with $23,289.9 \mathrm{~m}^{2}$ total area occurred during the final three years, and thus were included in the analyses of branchfall contributions. Branchfalls accounted for $23 \%$ of the total area and $40 \%$ of total number of disturbances in treefalls and branchfalls combined. Treefall and branchfall disturbance rates varied largely in parallel (Fig. 7, Fig. S8). Branchfalls were a larger proportion of events and area in some measurement periods than others. The ratio of area in branchfalls to area in treefalls ranged from 0.07 to 1.4 among measurement periods (Fig. 7a), and the ratio of number of branchfalls to number of treefalls ranged from 0.2 to 2.3 (Fig. 7 b). Standing dead trees accounted for $6.6 \%$ of the total number and $6.7 \%$ of the total area of mapped canopy disturbances.

(a)

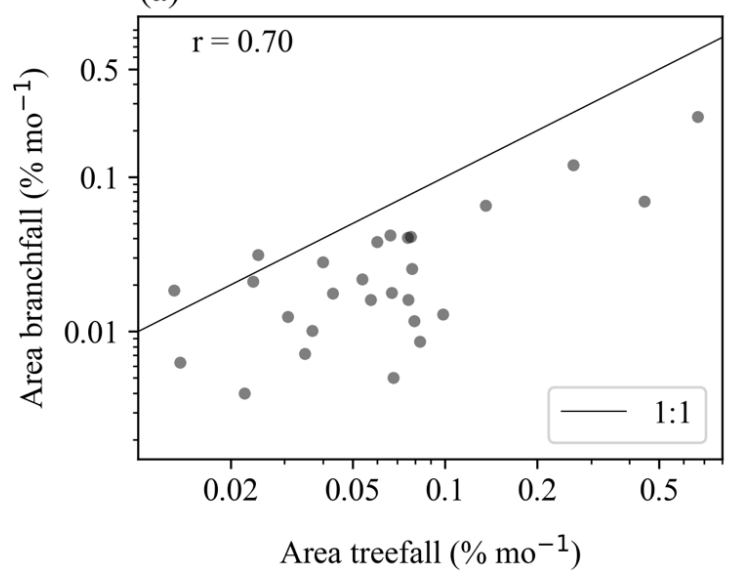

(b)

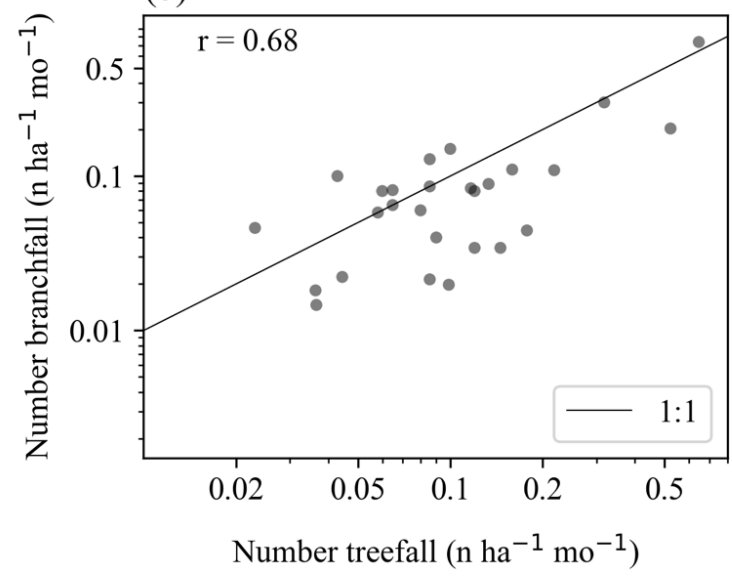

274 Figure 7. Relationship of temporal variation in branchfall rates to temporal variation in treefall rates, when measured by total area 275 (a) and number of events (b). This includes measurement intervals from 23 December 2016 to 28 November 2019. 
https://doi.org/10.5194/bg-2021-102

Preprint. Discussion started: 20 April 2021

(c) Author(s) 2021. CC BY 4.0 License.

(c) (i)

\section{Discussion}

The use of high frequency (approximately monthly) drone imagery enabled us to quantify temporal variation in canopy disturbance rates and to quantify the sizes of canopy disturbances at high temporal and spatial resolutions. We found that canopy disturbance rates of the BCI 50 ha plot varied strongly over time, and were higher in the wet season. The frequency of extreme rainfall events was the single best predictor of monthly variation in canopy disturbance rate during the 5-year study period. In contrast, maximum horizontal wind speed was not significantly related. The size distribution of canopy disturbances was close to a power function for larger canopy disturbances, but best fit by a Weibull function overall. Branchfalls accounted for $23 \%$ of the total area of disturbances from treefalls and branchfalls combined, and branchfall rates varied largely in parallel with treefall rates over time. These findings contributed to an improved understanding of the size distribution, temporal variation and meteorological drivers of canopy disturbances in tropical forests.

\subsection{Temporal variation in canopy disturbance}

Canopy disturbance rates varied strongly over time in this moist tropical forest, and were higher in the wet season. A single time interval (June 1 to July 13 2016) accounted for $21 \%$ of the total disturbed area of the BCI 50-ha plot. Treefall and branchfall disturbance rates varied largely in parallel, but not entirely. Some of the differences in temporal patterns simply reflect the stochastic nature of these processes, but different temporal patterns in branchfalls vs. treefalls could also reflect different sensitivity to particular abiotic drivers (e.g. wind regime, soil saturation). The frequency of rainfall events $>35.7 \mathrm{~mm} \mathrm{hour}^{-1}$ explained much of the variation in canopy disturbance rates among measurement intervals, whereas the frequency of high maximum horizontal wind speeds was not related. At our site, horizontal wind speeds are higher during the dry season, when canopy disturbance rates are lower (Fig. 4a, Fig. S1). We hypothesize that extreme high rainfall is associated with both saturated soils, increasing risk of uprooting, and with gusts having high horizontal and vertical windspeeds that increase stresses on tree crowns. Future studies should include high frequency measurements of vertical and horizontal windspeeds and soil moisture to better capture proximate drivers, and evaluate mechanistically formulated predicted models that include multiple variables.

These results are consistent with previous findings on seasonal variation and the role of rainfall in gap formation in tropical forests. A previous 4-year study on BCI found seasonal peaks in August and September, in the middle of the wet season, with monthly treefall rates significantly correlated with rainfall $(\mathrm{r}=0.47, \mathrm{p}<0.02)$ (Brokaw, 1982). Tree mortality was also strongly and positively correlated with monthly rainfall $(\mathrm{r}=0.85)$ in a 1-year study of a 10-ha site in the Central Amazon (Fontes et al., 2018). A study monitored canopy trees monthly over five decades in the Central Amazon and found that trees died more often during wet months, even in drought years (Aleixo et al., 2019). A regional study of the Central Amazon based on 12 years of satellite data found that major windthrows (visible on LANDSAT) occurred more frequently between September and February, months characterized by heavy rainfall, than the rest of the year (Negrón-Juárez et al., 2017). Analysis of spatial variation in forest damage from Hurricane María in Puerto Rico found that total rainfall was the most important meteorological risk factor and maximum sustained one-minute wind speeds the second-most-important; these two variables were moderately correlated $(r=0.43)$ (Hall et al., 2020).

Multiple studies have highlighted the importance of mesoscale convective systems, such as squall lines, for windthrows (Garstang et al., 1998; Negrón-Juárez et al., 2010, 2017; Araujo et al., 2017). In Panama, the period of June to August has the higher number of mesoscale convective systems (Jaramillo et al., 2017), and these were the months when we observed the highest 
https://doi.org/10.5194/bg-2021-102

Preprint. Discussion started: 20 April 2021

(C) Author(s) 2021. CC BY 4.0 License.

(c) (i) predictor of canopy disturbance formation in our study, is six times higher than the mean rate for mesoscale convective systems in the Panama region (Jaramillo et al., 2017), highlighting the importance of extreme events.

\subsection{Mechanisms and size structure canopy disturbances}

Gaps in the forest canopy can be caused proximally by treefalls of canopy trees, branchfalls of canopy branches, standing dead canopy trees, or senescing major canopy branches. Treefalls and branchfalls of canopy trees are well-captured in our analyses, which focus on short-term changes that indicate loss of major canopy elements. In contrast, standing dead trees and senescing branches generally involve more subtle changes in the canopy over a longer period of time, and may be missed by our methods. Treefalls account for a majority of canopy tree mortality in most tropical forests, but standing tree mortality also plays a major role, especially in drought periods. Overall, treefalls (in which trees were uprooted or their trunks snapped) accounted for $51.2 \%$ of all mortality of trees $>10 \mathrm{~cm}$ DBH in a large-scale study of tree mortality in 189 Amazonian plots (Esquivel-Muelbert et al., 2020 ) and $65 \%$ in a study that monitored tree mortality in 10 ha of forest in the Central Amazon bi-monthly over one year (Fontes et al., 2018). Treefalls can involve a single canopy tree, or multiple canopy trees. Multi-tree treefalls can result from coordinated disturbances over a large area (e.g., large footprint wind disturbance) and/or from domino effects in which the failure of one canopy tree directly stresses one or more neighboring trees and causes them to fall as well (e.g., when additional trees are knocked down by the first tree, or pulled down because of connections via lianas). It has been hypothesized that canopy disturbances may also be contagious over longer time intervals, with increased risk of treefall near canopy gaps, but evidence for this in tropical forests is mixed (Jansen et al., 2008). Given that our measurement intervals are relatively short ( one month), almost all of our mapped canopy disturbances are likely to reflect single catastrophic events.

Our study is one of several that have documented size distributions of canopy disturbances (dynamic gaps) or of static canopy gaps above some size that are approximately power functions, both on BCI (Solé and Manrubia, 1995; Lobo and Dalling, 2014) and in other tropical forests (Marvin and Asner, 2016; Asner et al., 2013; Kellner and Asner, 2009; Silva et al., 2019; Fisher et al., 2008). Static canopy gaps are areas in which the forest canopy is below a threshold height, e.g., $10 \mathrm{~m}$, at a given time. A power function distribution of disturbance event sizes (here canopy disturbances) and of the sizes of disturbed areas (canopy gaps) can emerge from self-organization of dynamic systems such as forests (Solé and Manrubia, 1995). These same self-organized dynamics lead to the development of equilibrium size distributions of trees, which are typically well-fit by Weibull distributions in tropical forests (Muller-Landau et al., 2006b, a). The relative dearth of canopy disturbances smaller than $25 \mathrm{~m}^{2}$ in our dataset, compared to what would be expected under a power function, may be explained in part by lower detection frequencies. Our methods are expected to capture all treefall and branchfalls above this threshold, but we may increasingly have missed smaller events, especially below $\sim 5 \mathrm{~m}^{2}$. However, we consider it unlikely that this is a sufficient explanation for the shortfall in small trees, and suggest that it is more likely explained largely by the low frequency of small trees and branches in the canopy of this mature tropical forest, and thus a scarcity of small treefall and branchfall events. 
https://doi.org/10.5194/bg-2021-102

Preprint. Discussion started: 20 April 2021

(c) Author(s) 2021. CC BY 4.0 License.

(c) (i)

349 forest found that $44 \%$ were branchfalls, and that they accounted for $15 \%$ of the total affected area (Leitold et al., 2018). In contrast,

350 a landscape level analysis of LiDAR data concluded that branchfalls were seven times more frequent than treefalls and accounted

351 for five times more area (Marvin and Asner, 2016). However, this study classified branchfalls and treefalls based purely on the 352 proportional decrease in canopy height (10-40\% decrease and 70-100\% decrease, respectively), a process liable to

353 misclassification, it entirely ignored disturbances involving intermediate decreases in canopy height (40-70\%), and did not 354 consider the possibility that any of these disturbances might be standing dead trees. Thus the contrast between our findings and 355 those of Marvin and Asner (2016) on the contributions of branchfalls may be due as much to methodological differences as to real 356 variation in canopy dynamics.

\section{Conclusions and future directions}

A mechanistic understanding of the controls on woody residence time in tropical forests is urgently needed to predict the future of tropical forest carbon stocks and biodiversity under global change. Canopy trees account for a majority of the productivity and carbon stocks in tropical forests, and their fates are disproportionately important for determining stand-level woody residence time. Advances in drone hardware and photogrammetric software now make it relatively inexpensive and straightforward to quantify forest canopy structure and dynamics at high spatial and temporal resolution through digital aerial photogrammetry and repeat drone imagery acquisitions. Here we applied these methods to 50 ha of old-growth tropical forest for five years, and analyzed the resulting products to quantify major drops in canopy height such as those created by branchfalls and treefalls, and thus calculate the canopy disturbance rate. We found that canopy disturbance rates are highly temporally variable, and are wellpredicted by extreme rainfall events. Even higher temporal resolution canopy dynamics data together with higher frequency threedimensional wind data would enable an even stronger assessment of the link to storm conditions, and additional analyses of the photogrammetry data could shed light on standing tree mortality. The expansion of these methods to additional and larger areas, potentially in part through citizen science initiatives, has great potential to improve our understanding of tropical forest tree mortality, and the future of tropical forests under changing climate regimes.

Code and data availability. Analysis codes, input data and output results are available at 374 https://github.com/forestgeo/gap_dynamics_BCI50ha. All files will be published in a permanent form at Smithsonian Figshare repository 10.25573 /data.c.5389043 when the manuscript is published in final form. manuscript. 
https://doi.org/10.5194/bg-2021-102

Preprint. Discussion started: 20 April 2021

(C) Author(s) 2021. CC BY 4.0 License.

Acknowledgments. We gratefully acknowledge the financial support of the Next Generation Ecosystem Experiments-Tropics, funded by the U.S. Department of Energy, Office of Science, Office of Biological and Environmental Research (RFA), the Smithsonian Institution Competitive Grants Program for Science (HCM, JD), and the Smithsonian Tropical Research Institute fellowship program (CHSC, RFA). We thank Milton Solano, Pablo Ramos, and Paulino Villareal for assistance in collecting and processing the drone imagery, and Jeffrey Chambers, KC Cushman and Evan Gora for providing helpful comments on an earlier version of this manuscript

\section{References}

Aleixo, I., Norris, D., Hemerik, L., Barbosa, A., Prata, E., Costa, F., and Poorter, L.: Amazonian rainforest tree mortality driven by climate and functional traits, Nat. Clim. Chang., 9, 384-388, https://doi.org/10.1038/s41558-019-0458-0, 2019.

Araujo, R. F., Nelson, B. W., Celes, C. H. S., and Chambers, J. Q.: Regional distribution of large blowdown patches across

394 Amazonia in 2005 caused by a single convective squall line: Distribution of Amazonia Blowdown Damage, Geophys. Res. Lett., 395 44, 7793-7798, https://doi.org/10.1002/2017GL073564, 2017.

Araujo, R. F., Chambers, J. Q., Celes, C. H. S., Muller-Landau, H. C., Santos, A. P. F. dos, Emmert, F., Ribeiro, G. H. P. M., Gimenez, B. O., Lima, A. J. N., Campos, M. A. A., and Higuchi, N.: Integrating high resolution drone imagery and forest inventory to distinguish canopy and understory trees and quantify their contributions to forest structure and dynamics, PLoS

ONE, 15, e0243079, https://doi.org/10.1371/journal.pone.0243079, 2020.

Arellano, G., Medina, N. G., Tan, S., Mohamad, M., and Davies, S. J.: Crown damage and the mortality of tropical trees, New

Phytol, 221, 169-179, https://doi.org/10.1111/nph.15381, 2019.

Asner, G. P., Kellner, J. R., Kennedy-Bowdoin, T., Knapp, D. E., Anderson, C., and Martin, R. E.: Forest Canopy Gap

Brienen, R. J. W., Phillips, O. L., Feldpausch, T. R., Gloor, E., Baker, T. R., Lloyd, J., Lopez-Gonzalez, G., MonteagudoMendoza, A., Malhi, Y., Lewis, S. L., Vásquez Martinez, R., Alexiades, M., Álvarez Dávila, E., Alvarez-Loayza, P., Andrade, A., Aragão, L. E. O. C., Araujo-Murakami, A., Arets, E. J. M. M., Arroyo, L., Aymard C., G. A., Bánki, O. S., Baraloto, C., Barroso, J., Bonal, D., Boot, R. G. A., Camargo, J. L. C., Castilho, C. V., Chama, V., Chao, K. J., Chave, J., Comiskey, J. A., Cornejo Valverde, F., da Costa, L., de Oliveira, E. A., Di Fiore, A., Erwin, T. L., Fauset, S., Forsthofer, M., Galbraith, D. R., Grahame, E. S., Groot, N., Hérault, B., Higuchi, N., Honorio Coronado, E. N., Keeling, H., Killeen, T. J., Laurance, W. F., Laurance, S., Licona, J., Magnussen, W. E., Marimon, B. S., Marimon-Junior, B. H., Mendoza, C., Neill, D. A., Nogueira, E. M., Núñez, P., Pallqui Camacho, N. C., Parada, A., Pardo-Molina, G., Peacock, J., Peña-Claros, M., Pickavance, G. C., Pitman, N. C. 414 A., Poorter, L., Prieto, A., Quesada, C. A., Ramírez, F., Ramírez-Angulo, H., Restrepo, Z., Roopsind, A., Rudas, A., Salomão, R. 415 P., Schwarz, M., Silva, N., Silva-Espejo, J. E., Silveira, M., Stropp, J., Talbot, J., ter Steege, H., Teran-Aguilar, J., Terborgh, J., 416 Thomas-Caesar, R., Toledo, M., Torello-Raventos, M., Umetsu, R. K., van der Heijden, G. M. F., van der Hout, P., Guimarães

417 Vieira, I. C., Vieira, S. A., Vilanova, E., Vos, V. A., and Zagt, R. J.: Long-term decline of the Amazon carbon sink, Nature, 519, 418 344-348, https://doi.org/10.1038/nature14283, 2015. 
https://doi.org/10.5194/bg-2021-102

Preprint. Discussion started: 20 April 2021

(c) Author(s) 2021. CC BY 4.0 License.

Dalagnol, R., Wagner, F. H., Galvão, L. S., Streher, A. S., Phillips, O. L., Gloor, E., Pugh, T. A. M., Ometto, J. P. H. B., and Aragão, L. E. O. C.: Large-scale variations in the dynamics of Amazon forest canopy gaps from airborne lidar data and opportunities for tree mortality estimates, Sci Rep, 11, 1388, https://doi.org/10.1038/s41598-020-80809-w, 2021.

427 Dalling, J. W., Winter, K., and Hubbell, S. P.: Variation in growth responses of neotropical pioneers to simulated forest gaps,

428 Funct Ecology, 18, 725-736, https://doi.org/10.1111/j.0269-8463.2004.00868.x, 2004.

429 Dandois, J. P. and Ellis, E. C.: High spatial resolution three-dimensional mapping of vegetation spectral dynamics using computer vision, Remote Sensing of Environment, 136, 259-276, https://doi.org/10.1016/j.rse.2013.04.005, 2013.

Davies, S. J., Abiem, I., Abu Salim, K., Aguilar, S., Allen, D., Alonso, A., Anderson-Teixeira, K., Andrade, A., Arellano, G., Ashton, P. S., Baker, P. J., Baker, M. E., Baltzer, J. L., Basset, Y., Bissiengou, P., Bohlman, S., Bourg, N. A., Brockelman, W. Y., Bunyavejchewin, S., Burslem, D. F. R. P., Cao, M., Cárdenas, D., Chang, L.-W., Chang-Yang, C.-H., Chao, K.-J., Chao, W.C., Chapman, H., Chen, Y.-Y., Chisholm, R. A., Chu, C., Chuyong, G., Clay, K., Comita, L. S., Condit, R., Cordell, S., Dattaraja, H. S., de Oliveira, A. A., den Ouden, J., Detto, M., Dick, C., Du, X., Duque, Á., Ediriweera, S., Ellis, E. C., Obiang, N. L. E., Esufali, S., Ewango, C. E. N., Fernando, E. S., Filip, J., Fischer, G. A., Foster, R., Giambelluca, T., Giardina, C., Gilbert, G. S., Gonzalez-Akre, E., Gunatilleke, I. A. U. N., Gunatilleke, C. V. S., Hao, Z., Hau, B. C. H., He, F., Ni, H., Howe, R. W., Hubbell, S. P., Huth, A., Inman-Narahari, F., Itoh, A., Janík, D., Jansen, P. A., Jiang, M., Johnson, D. J., Jones, F. A., Kanzaki, M., Kenfack, D., Kiratiprayoon, S., Král, K., Krizel, L., Lao, S., Larson, A. J., Li, Y., Li, X., Litton, C. M., Liu, Y., Liu, S., Lum, S. K. Y., Luskin, M. S., Lutz, J. A., Luu, H. T., Ma, K., Makana, J.-R., Malhi, Y., Martin, A., McCarthy, C., McMahon, S. M., McShea, W. J., Memiaghe, H., Mi, X., Mitre, D., Mohamad, M., Monks, L., et al.: ForestGEO: Understanding forest diversity and dynamics through a global observatory network, Biological Conservation, 253, 108907, https://doi.org/10.1016/j.biocon.2020.108907, 2021.

Deb, J., Phinn, S., Butt, N., and Mcalpine, C.: Climate change impacts on tropical forests: identifying risks for tropical Asia, JTFS, 30, 182-194, https://doi.org/10.26525/jtfs2018.30.2.182194, 2018.

Denslow, J. S.: Patterns of plant species diversity during succession under different disturbance regimes, Oecologia, 46, 18-21, https://doi.org/10.1007/BF00346960, 1980.

Denslow, J. S.: Tropical Rainforest Gaps and Tree Species Diversity, 1, 431-451, 1987.

Esquivel-Muelbert, A., Phillips, O. L., Brienen, R. J. W., Fauset, S., Sullivan, M. J. P., Baker, T. R., Chao, K.-J., Feldpausch, T. R., Gloor, E., Higuchi, N., Houwing-Duistermaat, J., Lloyd, J., Liu, H., Malhi, Y., Marimon, B., Marimon Junior, B. H., Monteagudo-Mendoza, A., Poorter, L., Silveira, M., Torre, E. V., Dávila, E. A., del Aguila Pasquel, J., Almeida, E., Loayza, P. A., Andrade, A., Aragão, L. E. O. C., Araujo-Murakami, A., Arets, E., Arroyo, L., Aymard C., G. A., Baisie, M., Baraloto, C., Camargo, P. B., Barroso, J., Blanc, L., Bonal, D., Bongers, F., Boot, R., Brown, F., Burban, B., Camargo, J. L., Castro, W., Moscoso, V. C., Chave, J., Comiskey, J., Valverde, F. C., da Costa, A. L., Cardozo, N. D., Di Fiore, A., Dourdain, A., Erwin, T., Llampazo, G. F., Vieira, I. C. G., Herrera, R., Honorio Coronado, E., Huamantupa-Chuquimaco, I., Jimenez-Rojas, E., Killeen, T., Laurance, S., Laurance, W., Levesley, A., Lewis, S. L., Ladvocat, K. L. L. M., Lopez-Gonzalez, G., Lovejoy, T., Meir, P., Mendoza, C., Morandi, P., Neill, D., Nogueira Lima, A. J., Vargas, P. N., de Oliveira, E. A., Camacho, N. P., Pardo, G., Peacock, J., Peña-Claros, M., Peñuela-Mora, M. C., Pickavance, G., Pipoly, J., Pitman, N., Prieto, A., Pugh, T. A. M., Quesada, C., Ramirez-Angulo, H., de Almeida Reis, S. M., Rejou-Machain, M., Correa, Z. R., Bayona, L. R., Rudas, A., Salomão, R., Serrano, J., Espejo, J. S., Silva, N., Singh, J., Stahl, C., Stropp, J., Swamy, V., Talbot, J., ter Steege, H., et al.: Tree mode of death and mortality risk factors across Amazon forests, Nat Commun, 11, 5515, https://doi.org/10.1038/s41467-020-18996-3, 2020.

463

464

465

466 467

468 469
Fisher, J. I., Hurtt, G. C., Thomas, R. Q., and Chambers, J. Q.: Clustered disturbances lead to bias in large-scale estimates based on forest sample plots: Clustered disturbance and forest plot bias, 11, 554-563, https://doi.org/10.1111/j.14610248.2008.01169.x, 2008 .

Fontes, C. G., Chambers, J. Q., and Higuchi, N.: Revealing the causes and temporal distribution of tree mortality in Central Amazonia, Forest Ecology and Management, 424, 177-183, https://doi.org/10.1016/j.foreco.2018.05.002, 2018.

Garstang, M., White, S., Shugart, H. H., and Halverson, J.: Convective cloud downdrafts as the cause of large blowdowns in the Amazon rainforest, Meteorl. Atmos. Phys., 67, 199-212, https://doi.org/10.1007/BF01277510, 1998. 
https://doi.org/10.5194/bg-2021-102

Preprint. Discussion started: 20 April 2021

(C) Author(s) 2021. CC BY 4.0 License.

Hall, J., Muscarella, R., Quebbeman, A., Arellano, G., Thompson, J., Zimmerman, J. K., and Uriarte, M.: Hurricane-Induced Rainfall is a Stronger Predictor of Tropical Forest Damage in Puerto Rico Than Maximum Wind Speeds, Sci Rep, 10, 4318,

472 https://doi.org/10.1038/s41598-020-61164-2, 2020.

473 Harms, K. E., Condit, R., Hubbell, S. P., and Foster, R. B.: Habitat associations of trees and shrubs in a 50-ha neotropical forest 474 plot: Habitat associations of trees and shrubs, 89, 947-959, https://doi.org/10.1111/j.1365-2745.2001.00615.x, 2001.

475 Holdridge, L. R.: Determination of World Plant Formations from Simple Climatic Data, 105, 367-368, 1947.

476 Hubbell, S. P., Foster, R. B., O’Brien, S. T., Harms, K. E., Condit, R., Wechsler, B., Wright, S. J., and Loo de Lao, S.: Light-Gap 477 Disturbances, Recruitment Limitation, and Tree Diversity in a Neotropical Forest, 283, 554-557,

478 https://doi.org/10.1126/science.283.5401.554, 1999.

IPCC: Summary for Policymakers, in: Climate Change 2014, Mitigation of Climate Change. Contribution of Working Group III to the Fifth Assessment Report of the Intergovernmental Panel on Climate Change, Cambridge University Press, United

481 Kingdom and New York, NY, USA, 2014.

482 Jansen, P. A., Meer, P. J. V. der, and Bongers, F.: SPATIAL CONTAGIOUSNESS OF CANOPY DISTURBANCE IN 483 TROPICAL RAIN FOREST: AN INDIVIDUAL-TREE-BASED TEST, Ecology, 89, 3490-3502, https://doi.org/10.1890/07$484 \quad 1682.1,2008$.

485 Jaramillo, L., Poveda, G., and Mejía, J. F.: Mesoscale convective systems and other precipitation features over the tropical 486 Americas and surrounding seas as seen by TRMM: MESOSCALE CONVECTIVE SYSTEMS IN TROPICAL AMERICAS, Int. 487 J. Climatol, 37, 380-397, https://doi.org/10.1002/joc.5009, 2017.

488 Kellner, J. R. and Asner, G. P.: Convergent structural responses of tropical forests to diverse disturbance regimes, 12, 887-897, 489 https://doi.org/10.1111/j.1461-0248.2009.01345.x, 2009.

490 Leigh, E. G. Jr.: Tropical forest ecology: a view from Barro Colorado Island, Oxford University Press, Oxford, 1999.

491 Leitold, V., Morton, D. C., Longo, M., dos-Santos, M. N., Keller, M., and Scaranello, M.: El Niño drought increased canopy 492 turnover in Amazon forests, New Phytol, 219, 959-971, https://doi.org/10.1111/nph.15110, 2018.

493 Lobo, E. and Dalling, J. W.: Effects of topography, soil type and forest age on the frequency and size distribution of canopy gap 494 disturbances in a tropical forest, Biogeosciences, 10, 6769-6781, https://doi.org/10.5194/bg-10-6769-2013, 2013.

495 Lobo, E. and Dalling, J. W.: Spatial scale and sampling resolution affect measures of gap disturbance in a lowland tropical

496 forest: implications for understanding forest regeneration and carbon storage, Proc. R. Soc. B., 281, 20133218,

497 https://doi.org/10.1098/rspb.2013.3218, 2014.

498 Manrubia, S. C. and Solé, R. V.: On Forest Spatial Dynamics with Gap Formation, Journal of Theoretical Biology, 187, 159-

499 164, https://doi.org/10.1006/jtbi.1997.0409, 1997.

500 Marra, D. M., Chambers, J. Q., Higuchi, N., and Trumbore, S. E.: Large-Scale Wind Disturbances Promote Tree Diversity in a 501 Central Amazon Forest, 9, 16, 2014.

502 Marvin, D. C. and Asner, G. P.: Branchfall dominates annual carbon flux across lowland Amazonian forests, Environ. Res. Lett., 503 11, 094027, https://doi.org/10.1088/1748-9326/11/9/094027, 2016.

504 McDowell, N., Allen, C. D., Anderson-Teixeira, K., Brando, P., Brienen, R., Chambers, J., Christoffersen, B., Davies, S., 505 Doughty, C., Duque, A., Espirito-Santo, F., Fisher, R., Fontes, C. G., Galbraith, D., Goodsman, D., Grossiord, C., Hartmann, H., 506 Holm, J., Johnson, D. J., Kassim, Abd. R., Keller, M., Koven, C., Kueppers, L., Kumagai, T., Malhi, Y., McMahon, S. M.,

507 Mencuccini, M., Meir, P., Moorcroft, P., Muller-Landau, H. C., Phillips, O. L., Powell, T., Sierra, C. A., Sperry, J., Warren, J., $508 \mathrm{Xu}, \mathrm{C}$., and $\mathrm{Xu}, \mathrm{X}$.: Drivers and mechanisms of tree mortality in moist tropical forests, New Phytol, 219, 851-869,

509 https://doi.org/10.1111/nph.15027, 2018.

510 McMahon, S. M., Arellano, G., and Davies, S. J.: The importance and challenges of detecting changes in forest mortality rates, 511 Ecosphere, 10, e02615, https://doi.org/10.1002/ecs2.2615, 2019. 
https://doi.org/10.5194/bg-2021-102

Preprint. Discussion started: 20 April 2021

(c) Author(s) 2021. CC BY 4.0 License.

Muller-Landau, H. C., Condit, R. S., Harms, K. E., Marks, C. O., Thomas, S. C., Bunyavejchewin, S., Chuyong, G., Co, L.,

513 Davies, S., Foster, R., Gunatilleke, S., Gunatilleke, N., Hart, T., Hubbell, S. P., Itoh, A., Kassim, A. R., Kenfack, D., LaFrankie,

514 J. V., Lagunzad, D., Lee, H. S., Losos, E., Makana, J.-R., Ohkubo, T., Samper, C., Sukumar, R., Sun, I.-F., Nur Supardi, M. N.,

515 Tan, S., Thomas, D., Thompson, J., Valencia, R., Vallejo, M. I., Munoz, G. V., Yamakura, T., Zimmerman, J. K., Dattaraja, H.

516 S., Esufali, S., Hall, P., He, F., Hernandez, C., Kiratiprayoon, S., Suresh, H. S., Wills, C., and Ashton, P.: Comparing tropical

517 forest tree size distributions with the predictions of metabolic ecology and equilibrium models, Ecol Letters, 9, 589-602,

518 https://doi.org/10.1111/j.1461-0248.2006.00915.x, 2006a.

519 Muller-Landau, H. C., Condit, R. S., Chave, J., Thomas, S. C., Bohlman, S. A., Bunyavejchewin, S., Davies, S., Foster, R., 520 Gunatilleke, S., Gunatilleke, N., Harms, K. E., Hart, T., Hubbell, S. P., Itoh, A., Kassim, A. R., LaFrankie, J. V., Lee, H. S., Losos, E., Makana, J.-R., Ohkubo, T., Sukumar, R., Sun, I.-F., Nur Supardi, M. N., Tan, S., Thompson, J., Valencia, R., Munoz, G. V., Wills, C., Yamakura, T., Chuyong, G., Dattaraja, H. S., Esufali, S., Hall, P., Hernandez, C., Kenfack, D., Kiratiprayoon, S., Suresh, H. S., Thomas, D., Vallejo, M. I., and Ashton, P.: Testing metabolic ecology theory for allometric scaling of tree size, growth and mortality in tropical forests, Ecol Letters, 9, 575-588, https://doi.org/10.1111/j.1461-0248.2006.00904.x, 2006b.

Negrón-Juárez, R. I., Chambers, J. Q., Guimaraes, G., Zeng, H., Raupp, C. F. M., Marra, D. M., Ribeiro, G. H. P. M., Saatchi, S. S., Nelson, B. W., and Higuchi, N.: Widespread Amazon forest tree mortality from a single cross-basin squall line event: WINDDRIVEN TREE MORTALITY IN AMAZONIA, Geophys. Res. Lett., 37, n/a-n/a, https://doi.org/10.1029/2010GL043733,

5282010

Negrón-Juárez, R. I., Jenkins, H. S., Raupp, C. F. M., Riley, W. J., Kueppers, L. M., and Marra, D. M.: Windthrow Variability in Central Amazonia, 17, 2017.

531 Negrón-Juárez, R. I., Holm, J. A., Marra, D. M., Rifai, S. W., Riley, W. J., Chambers, J. Q., Koven, C. D., Knox, R. G., 532 McGroddy, M. E., Di Vittorio, A. V., Urquiza-Muñoz, J., Tello-Espinoza, R., Muñoz, W. A., Ribeiro, G. H. P. M., and Higuchi, 533 N.: Vulnerability of Amazon forests to storm-driven tree mortality, Environ. Res. Lett., 13, 054021,

534 https://doi.org/10.1088/1748-9326/aabe9f, 2018.

535 Pan, Y., Birdsey, R. A., Phillips, O. L., and Jackson, R. B.: The Structure, Distribution, and Biomass of the World's Forests, 536 Annu. Rev. Ecol. Evol. Syst., 44, 593-622, https://doi.org/10.1146/annurev-ecolsys-110512-135914, 2013.

Phillips, O. L., Lloyd, J., Malhi, Y., Monteagudo, A., Almeida, S., Davila, E. A., Amaral, I., Andelman, S., Andrade, A., Arroyo, L., Aymard, G., Baker, T. R., and Bonal, D.: Drought-mortality relationships for tropical forests, 16, 2010.

Silva, C. A., Valbuena, R., Pinagé, E. R., Mohan, M., Almeida, D. R. A., North Broadbent, E., Jaafar, W. S. W. M., Papa, D., Cardil, A., and Klauberg, C.: ForestGapR: An r Package for forest gap analysis from canopy height models, Methods Ecol Evol, 10, 1347-1356, https://doi.org/10.1111/2041-210X.13211, 2019.

Silva, C. V. J., Aragão, L. E. O. C., Barlow, J., Espirito-Santo, F., Young, P. J., Anderson, L. O., Berenguer, E., Brasil, I., Foster Brown, I., Castro, B., Farias, R., Ferreira, J., França, F., Graça, P. M. L. A., Kirsten, L., Lopes, A. P., Salimon, C., Scaranello, M. A., Seixas, M., Souza, F. C., and Xaud, H. A. M.: Drought-induced Amazonian wildfires instigate a decadal-scale disruption of forest carbon dynamics, Phil. Trans. R. Soc. B, 373, 20180043, https://doi.org/10.1098/rstb.2018.0043, 2018.

Solé, R. V. and Manrubia, S. C.: Are rainforests self-organized in a critical state?, Journal of Theoretical Biology, 173, 31-40, https://doi.org/10.1006/jtbi.1995.0040, 1995.

Windsor, D. M.: Climate and moisture variability in a tropical forest: long- term records from Barro Colorado Island, Panamá, 